\title{
РОЛЬ ВОЕННОГО ДУХОВЕНСТВА В БРУСИЛОВСКОМ ПРОРЫВЕ В ПЕРИОД ПЕРВОЙ МИРОВОЙ ВОЙНЫ
}

\section{THE ROLE OF THE MILITARY CLERGY IN THE BRUSILOVSKY BREAKTHROUGH DURING THE FIRST WORLD WAR}

Yu. Bezik

Summary: The phenomenon of the first large-scale war of the XX century. - The First World War cannot fail to amaze with the scale of the hostilities, the number of victims, the general senselessness of the policies of the world powers, leading «to nowhere.» Nevertheless, under the prevailing difficult conditions, Russian people showed qualities inherent in our people and helping in any emergency: kindness, courage, dedication, and the ability of faith. On the whole, priests who appeared on the fronts of the First World War showed the same. The situation, which is politically very ambiguous (both from the point of view of foreign policy determined by the interests of the elite related to the redistribution of colonies and sales markets; and from the point of view of domestic policy related to the tense revolutionary situation), led to the fact that sometimes the person played a key role in the sense of her human spirit, her desire to live and do good. The Brusilov breakthrough - an outstanding operation in many ways of the First World War - owes its non-standard character to the role of the individual - General Brusilov, Russian soldiers and priests - who tried their best to enlighten the spirit of Russian soldiers in a situation of political and economic collapse.

Keywords: World War I, military clergy, Brusilov, Brusilov breakthrough, personality, humanity, spiritual support, patriotism.
$\Pi$ ервая мировая война - безусловно, драматический период в русской и мировой истории. Имеющая в качестве причин, причины далекие от реальных потребностей воюющих народов, двигаемая в основном как это часто бывает правительствами, первая столь масштабная война в XX веке носила, если можно так выразиться, необратимый характер. Иными словами, не воевать в то время, по крайней мере будучи таким важным политическим игроком, как Россия, было невозможно. К сожалению, историю, тем более историю войн, двигают зачастую не мирные труженики, далекие от передела рынков и колоний, а амбициозные политики, часто забывающие о человеческом компоненте политического процесса.

Бедная не по своей вине, своеобразно деспотичная и очень патриотичная Россия к началу первой мировой войны, можно сказать, была достаточно экономически подготовлена, несмотря на многие накладки. [Еремин, 2015 - с. 93-96; Камынин, 2014 - с. 48-53; О готовности
Безик Юрий Иванович

К.воен.н., докторант, Общецерковная аспирантура и докторантура им. Святых равноапостольных Кирилла и Мефодия (г. Москва) bezikgeorgii@mail.ru

Аннотация: Феномен первой масштабной войны ХХ в. - Первой мировой войны не может не поражать масштабностью боевых действий, количеством жертв, общей бессмысленностью политики мировых держав, ведущей «в никуда». Тем не менее в сложившихся тяжелых условиях русские люди проявляли качества, присущие нашему народу и помогающие в любой экстренной ситуации: доброту, мужество, самоотверженность, способность веры. Это же в целом проявили священники, оказавшиеся на фронтах Первой мировой войны. Положение, политически весьма неоднозначное (как с точки зрения внешней политики, определявшейся интересами элиты, связанными с переделом колоний и рынков сбыта; так и с точки зрения внутренней политики, связанной с напряженной революционной ситуацией), приводило к тому, что ключевую роль порой играла личность в смысле ее человеческого настроя, ее желания жить и творить добро. Брусиловский прорыв - выдающаяся во многих смыслах операция Первой мировой войны - своей нестандартностью обязана именно роли личности - генерала Брусилова, русских солдат и священников - изо всех сил старавшихся просветлить дух русских воинов в ситуации политического и экономического краха.

Ключевые слова: Первая мировая война, военное духовенство, Брусилов, брусиловский прорыв, личность, человечность, духовная поддержка, патриотизм.

Российской империи к Первой мировой войне, 2014]. Это подтверждается достаточной конкурентностью русских, их неоднократной помощью сильнейшим державам мира того времени - Англии и Франции, союзникам по Антанте. При этом сам характер этой уже весьма техничной, очень масштабной «бойни» был достаточно неопределенным, что выразилось в таких терминах, как «окопная война», «позиционная война» [Первая мировая война 1914-191, 2019]. Дело в том, что, чем масштабнее военное противостояние, чем оно более технично, тем очевиднее становится, что это противостояние бессмысленно. А в случае мировой войны, когда кажется, что «все против всех», характер военных действий и вовсе часто принимает вид «неподвижной» локации тех или иных войск, что очень мешало чьим бы то ни было, каким бы то ни было победам и прорывам. Постепенно, конечно, это привело и к экономической разрухе.

Россия вступила в войну, о которой идет речь, воодушевленной. Катаклизмы, вызванные революционной 
ситуацией, произошли вследствие изменений внутри российского общества, государства и русской православной церкви [Белоус, 2017 - с. 18]. Однако, сложная революционная ситуация, которая определяла политический процесс в нашей стране по большому счету, на какое-то время «отступила» перед необходимостью представлять интересы Родины на международной арене [Недоступов, 2018 - с. 8-18; Кузнецова, 2018 - с. 176178; «Война сильнее всяких проповедей учит нас патриотизму», 2014]. Как уже было казано, довольно часто в процессе этой войны мы помогали нашим союзникам по Антанте, имевшим тогда наибольший политический вес в мире (собственно, именно желая противостоять этому весу Германия и развязала войну). Англия и Франция оттягивали наши силы, ибо международные обязательства Россия всегда выполняла. При этом, как мы уже сказали, яркими эпизодами война, о которой идет речь, в принципе не отличается. Тем более в плане защиты Россией своих (чисто военных) интересов - чему мешали и просьбы союзников, и революционная ситуация, которая, кстати, по большому счету, не ограничивалась российской территорией.

Если говорить о заметных победах, точнее определенных прорывах России в период с 1914 (начало войны, спровоцированное убийством наследника австрийского престола) по 1918 гг. (когда был заключен сепаратный Брестский мир), то следует признать, что самым заметным явлением здесь стал Брусиловский прорыв - названный по имени талантливого, умного и волевого командующего А.А. Брусилова, назначенного впоследствии главнокомандующим. Одно из высказываний этого военачальника, к которому достаточно хорошо относились в войсках, глубоко характеризует и драматичность первой мировой, и ее «странный» характер, и дух русских солдат, и волю самого Брусилова - речь идет о приказе начдиву 12-й кавалерийской дивизии А.М. Каледину, датируемом 29.08.1914 и содержащем слова: «Умереть, но умирать не сразу, а продержаться до вечера»... [«Приказываю - умереть!», 1963]. Надо сказать, что Брусиловский прорыв изначально был назван Луцким - по географическому признаку, но из уважения к человеку, совершившему прорыв в теории и практике военного дела, предвосхитившему победы Великой Отечественной (что отмечают даже наши политические, идеологические противники), данная операция была названа по имени ее автора - что представляет практически единственный случай в истории [Кречетников, 2016; Брусиловский прорыв в ходе Первой мировой войны (1916), 2016]! Что же это была за личность, был ли Брусилов верующим, какую именно роль сыграло военное священство в эпоху Первой мировой войны в целом и в ходе Брусиловского прорыва, «повернувшего вспять» войну, в частности?
В таких условиях, когда психологически ориентироваться порой было очень сложно, духовный настрой российских солдат, их еще достаточно заметная религиозность поддерживались идеологией Русской православной церкви. Говорить здесь подробно о связи Русской православной церкви и государства, видимо, не стоит, ибо этот вопрос достаточно сложен, являясь дискуссионным по многим причинам. Следует сказать, что, чем ближе священник, врач, кто-то другой был в этот период к народу, тем более он ориентировался на свои личностные, общесоциальные, культурные качества, характеристики, потому что иначе в сложившейся крайне неоднозначной ситуации нельзя было оставаться хоть сколько-то продуктивным - политическая составляющая процесса (как внутри страны, так и на международной арене), так сказать, трещала по всем швам. Люди тянулись друг к другу, всячески пытаясь помочь себе и другим, понимая, что мир глобальной политики предает их, он разбалансирован, кажется, с самой жизнью.

Войсковым священникам в данном случае было весьма нелегко, потому что в течение многих веков они находились в состоянии адекватного взаимовлияния как по отношению к народу, так и к государственному аппарату (все-таки триада консерватора XIX в. С.С. Уварова, связанная с самодережавием, православием и народностью, конечно, отражает в целом исторические закономерности) [Камалова, 2018 - с. 55-69]. Именно РПЦ на протяжении длительного времени была проводником господствующей в государстве религии и оказывала решающее воздействие на его судьбы [Давлетшин, 2004]. «Время любить, и время ненавидеть; время войне, и время миру» (Еккл. 3: 8). Эту фразу из книги Екклесиаста можно трактовать как своего рода указание на определенное место для войны в условиях нашего мира для всех людей. Сам Господь Иисус Христос предостерегал, что войны будут сопровождать человечество весь период его земного существования: «Также услышите о войнах и о военных слухах. Смотрите, не ужасайтесь, ибо надлежит всему тому быть, но это еще не конец» (Мф. 24: 6).

Как говорит автор статьи «Православное духовенство в годы первой мировой войны», «в массе своей лица духовного звания оставались с народом, разделяя с ним тяготы невиданной войны [Леонтьева, 2014 - с/104119]. В 1914-1918 гг. почти 40 священников погибли, около 400 получили ранения или контузии, более 200 оказались в плену. Война обернулась крушением многовекового союза государства и православной церкви. Как часть государственного механизма, РПЦ развалилась». Кроме того, связь между церковью и армией в России, установившаяся издавна, также просуществовала до 1917 г [Риффель, 1999]. Надо сказать, что подобная точка зрения для многих историков представляется достаточно очевидной. Это говорит о серьезном (серьезнее, чем 
кому-то кажется) духовном, организачионном, политическом кризисе России в начале $X X$ в., что важно осознать и сейчас. Повторим, что в такой ситуации важнейшую роль играли личные качества каждого человека, и священники здесь, выполняя особую роль, в массе своей, по-видимому, оставались добрыми, самоотверженными русскими людьми.

Указанная историческая статья «Православное духовенство в годы первой мировой войны» довольно разносторонне раскрывает самые разные противоречия кризисного времени (в том числе противоречия, связанные с самим священством), она дает подтверждение тому, что почти в каждой духовной семинарии, академии в тот период обнаружились добровольцы, желающие идти на фронт для пользы Отечества [Вениамин, 2004 - с. 170-171]! Можно отметить такие случаи, как случай молодых кишиневских священников «первого набора» - образованных, энергичных, самоотверженных, прошедших специальные медицинские курсы [Шавельский, 2005 - с. 445-446]. В один из полков прибыл служить обладатель университетского диплома А. Введенский [Левитин-Краснов, 1996 - с. 23]. Следует сказать о том, что, когда уже большой патриотический энтузиазм несколько иссяк (например, в 1916 г.), среди священников всетаки находилось немало тех, кто добровольцем желал отправиться на фронт, церковью собирались материальные средства для ведения войны [Леонтьева, 2014].

Особенно в начале войны, многие вернулись к забытым было обрядам молебнов, причастий, военные часто помогали священникам так или иначе обустраивать церковные места: однажды за ночь солдаты построили церковь из оконных рам и молодых деревьев, раненых выносили на носилках к алтарю [Амвросия, 2008 - с. 185; Вениамин, 1998 - с. 285]. Часто священники с большим риском для жизни совершали богослужения прямо в окопах [Амвросия, 2008 - с. 203, 225; Церковный вестник, 1914 - с. 44]. Война заставила людей переосмыслить смерть, глубоко и драматично заглянуть ей в глаза, а также в глаза друг другу [Амвросия, 2008 - с. 240-245]. При отпеваниях не забывали порой и противника... [Ксюнин, 1920 - с. 120]. Наблюдалось определенное религиозное единение с другими конфессиями, генерал А.Е. Снесарев после совместной рождественской службы с униатами, например, заявил: «Если наши духовные вожди не будут слишком формальными, возврат униатов в лоно Православной церкви совершится скоро и сам собою» [Снесарев, 2012 - с. 76]. Как пишет Т. Г. Леонтьева, «формальная обрядность уступала место естественной вере, обостренной близостью смерти. Враждующие комбатанты уже в 1915 г. на Пасху выходили друг к другу, христосовались, обменивались угощениями» ... [Леонтьева, 2014]. Священник сообщает: «Более высокого и чистого состояния на исповеди, чем со своими солдатами, я ни- когда не переживал. Душа открытая, раскаяние легкое, замечательные лица» [Церковный вестник, 1914 - с. 50]. Вряд ли эти слова неискренни. А проповедник В. Востоков вспоминал о случае, когда раненый русский солдат попросил раньше перевязать противника, ибо тот был сильнее ранен... [Леонтьева, 2014 - с. 104-119]

Итак, если не политически (несмотря на все старания), то психологически, организационно Русская православная церковь в основном старалась поддерживать народ. Что касается самого высшего воздействия религии, связанной с сущностью религиозного чувства, то здесь следует отметить: при том, что и священники, и паства лишь люди, не могущие не иметь недостатков, и иногда эти недостатки весьма существенны - они коренятся, например, в нежелании видеть историческую правду, реальный потенциал борьбы и т. п.; при всем этом высшие силы находятся с теми, кто искренен, кто желает правды и что-то делает для ее утверждения. С этой точки зрения, война, о которой идет речь, вероятно, в принципе должна считаться проигрышной (с учетом ложных целей военных действий), однако, чем более дельным является человек, чем он более одухотворен, тем больше вероятности того, что даже в очень кризисной ситуации высшие силы будут, так сказать, резонировать с его внутренним настроем, волей. С этой точки зрения как раз и интересен Брусиловский прорыв. Из каких компонентов складывается это явление, какова была реальная роль священников, ведомых высшими силами и помогавших воинству во время Брусиловского прорыва?

Конечно, общий правильный нравственный настрой, который имели русские люди на протяжении практически всей истории России, настрой, закалявшийся в испытаниях, определяет богохранимость нашей страны. Однако человек, созданный по образу и подобию Божьему, обладает свободой воли, определенной свободной действий, свободой нравственного выбора - индивидуального и социального. Именно это очень важно в экстремальной ситуации - тем более, когда ход мировой истории определялся в целом неправильно, с учетом войны, не нужной народам земли (напомним, что в Первой мировой участвовало около 2/3 тогдашнего населения земного шара, 38 из 59 независимых стран!) [Первая мировая война 1914-1918, 2019]. А.А. Брусилов, как многие в то время, был верующим человеком, не отличаясь при этом верой, бросающейся в глаза (этот человек, вероятно, вообще не бросался в глаза ничем, кроме выразительной прямоты характера и результатов своих дел; что касается формы веры, то она иногда носила экспериментальный характер, свойственный времени) 
[Куличкин, 2011]. Совершив неоднократно личный правильный нравственный выбор, приложив к этому гибкость, четкость ума, профессионализм, Брусилов продемонстрировал «чудо», которое оказалось возможно, потому что множество субъектов этой военной операции, включая священников - были настроены на прорыв, работали на него, нравственно заслуживая хоть какой-то награды в нелегкое время.

С точки зрения технической, тактика командующего, о котором идет речь, заключалась в наступлении сразу по нескольким, разнонаправленным векторам - что очень подходило в ситуации позиционной войны: «Главным «ноу-хау» Брусилова стало то, что его план наступления предусматривал не один, а несколько разнонаправленных ударов для прорыва фронта противника. До этой операции никто ни в России, ни в мире так не наступал» [Сидорчик, 2013]. К.А. Залесский говорит о человеческой живости, определенной нестандартности, гибкости мышления А.А. Брусилова: «В отличие от командующих другими фронтами, [он] не имел ни академического военного образования, ни реального боевого опыта. На первом этапе наступления он отдал инициативу подчиненным, ставя им только самые общие цели и позволяя действовать по обстановке. Но потом сам поверил в успех дерзкой операции и заставил уверовать других» [Историк Константин Залесский, 2016]. Залесский говорит о вере как об одном из ключевых компонентов достаточно живой натуры Брусилова. В свою очередь, необходимо отметить, что смиренное осознание своих сил рассматривается в Священном Писании как единственно правильное для верующего воина, «ибо не от множества войска бывает победа на войне, но с неба приходит сила» (1 Мак. 3: 19). Конечно, при этом генерал полагался не только на Божью помощь, но и отличался четкостью и глубиной мысли, дисциплинированностью, принципиальностью, достаточной образованностью. Более того он, можно сказать, до описываемой военной операции и после нее (уже в период Советской власти) отличался тягой к теории, много лет отдал преподаванию военной науки [Сидорчик, 2013].

Итак, руководитель, автор самой знаменитой операции Первой мировой войны был честен, умен, в определенной степени нестандартен, характеризовался патриотизмом и профессионализмом одновременно [Александров, 2009 - с. 13-19]. Отличаясь верой в себя, в людей, в необходимость прорыва, он был достаточно религиозен, чтобы обстоятельства ему благоприятствовали. Поэтому поведение священников, сопровождавших войска Брусилова, работавших с солдатами, офицерами, находившимися под командованием, влиянием личности, о которой идет речь, бросается в глаза как поведе- ние самоотверженно-прекрасное - способствовавшее, со своей стороны военному чуду. Особое значение в нем имела духовная подготовка праведных воинов перед битвой, заключающаяся, прежде всего, в правильном устремлении мыслей к Богу: «Если ополчится против меня полк, не убоится сердце мое; если восстанет на меня война, и тогда буду надеяться» (Пс. 26: 3).

В книге В.Е. Шамбарова «За Веру, Царя и Отечество», в главе, посвященной брусиловскому прорыву, написано: «На Юго-Западном фронте 9-й Казанский драгунский полк получил приказ атаковать, но не мог двинуться с места под жестоким огнем. Тогда вдруг полковой священник о. Василий (Шпичек), очень тихий и скромный человек, выехал на своей смирной лошадке вперед и крикнул: «За мной, ребята!» - и поскакал, безоружный, на врага. За ним ринулись офицеры, потом весь полк. И смели противника. Впрочем, такой подвиг был далеко не единичным. С крестом в руке поднимал в атаки лейбгвардии стрелков иеромонах о. Александр (Тарноуцкий), несколько священников погибло в рядах 318-го Черноморского полка. Часто священники брали на себя столь опасное дело, как вынос раненых с поля боя. Всего же за время войны 14 священнослужителей были награждены георгиевскими крестами, более 100 - наперсным крестом на георгиевской ленте. ...как разъяснял протопресвитер армии и флота Георгий Шавельский: «Пленение священника свидетельствует, что он находился на своем посту, а не пробавлялся в тылу, где не угрожает опасность» [Шамбаров, 2003]

Подводя итоги анализу роли военного духовенства в Брусиловском прорыве в годы Первой мировой войны, следует отметить, что лицам духовного звания удавалось поддерживать стойкость, боевой дух и патриотизм русских бойцов на фронтах за счет того, что сами представители военного духовенства продолжали являть чудеса доброты, храбрости и самоотверженности. Священники в период военных действий способствовали объединению русских людей в вере, в борьбе за справедливость, укрепляли их дух перед лицом смерти.

Безусловно, успешность Брусиловского прорыва связана с личностными качествами самого А.А. Брусилова, однако, не только с профессиональными: вера, являясь значимой составляющей его натуры, сыграла не последнюю роль в результате предпринятой русскими войсками военной операции. Велико было и значение военного духовенства, сопровождавшего Брусиловский прорыв не щадя собственной жизни, бросаясь безоружными на врага, вынося раненых с поля боя, священники оставались верными своему народу и Отечеству, а их личные подвиги и мужество вдохновляли солдат, были примером духовной стойкости в борьбе за правое дело. 


\section{ЛИТЕРАТУРА}

1. Александров Б.Ю. А.А. Брусилов как военный и общественно-политический деятель (историография и источники изучения проблемы) // Вестник Российского университета дружбы народов. Серия: История России. 2009. № 5. - С. 13-19.

2. Амвросия (Оберучева), мон. История одной старушки. М.: Изд-во храма свв. бесср. и чудотв. Космы и Дамиана на Маросейке, 2008. - С. 185, 203, 225, $240-245$.

3. Белоус П.В. Тобольская епархия русской православной церкви в годы Первой мировой войны (1914-1918): автореферат дисс. ... канд. ист. наук. Тюмень, 2017. - 35 с.

4. Брусилов А.А. Воспоминания. М.: Воениздат, 1963. -286 с.

5. Брусиловский прорыв в ходе Первой мировой войны (1916) // РИА Новости, 04.06.2016 // https://ria.ru/20160604/1442440337.html (дата 0бращения: 12.04.2020).

6. Вениамин (Федченков), митр. Божьи люди. Мои духовные встречи. -М.: Отчий дом, 1998. - 414 с.

7. Вениамин (Федченков), митр. На рубеже двух эпох. - М.: Изд-во «Правило веры», 2004. - С. 170-171.

8. «Война сильнее всяких проповедей учит нас патриотизму». Первая мировая и российская провинция, год 1914-й // Военное 0б0зрение, 23.01 .2014 // https://topwar.ru/38600-voyna-silnee-vsyakih-propovedey-uchit-nas-patriotizmu-pervaya-mirovaya-i-rossiyskaya-provinciya-god-1914-y.html (дата обращения: 12.04 .2020$)$.

9. Давлетшин В.Р. Военное духовенство в России XVIII - начале XX века и его деятельность по морально-психологическому обеспечению охраны государственной границы: исторический анализ: дисс. ... канд. ист. наук. - М., 2004. - 233 с.

10. Еремин И.А. Степень готовности России к Первой мировой войне в оценках дореволюционных, советских и современных исследователей // Известия Алтайского государственного университета. 2015. № 3-2 (87). - С. 93-96.

11. Историк Константин Залесский: «Брусиловский прорыв спас западных союзников. Но те отплатили России неблагодарностью» (интервью Э. Чеснокова с К. Залесским) // Комсомольская правда, 04.06.2016 // https://www.kp.ru/best/msk/brusilov/ (дата обращения: 12.04.2020).

12. Камалова А.А. Взаимодействие государства и Русской православной церкви в дореволюционной России // Вестник Московского государственного областного университета. 2018. № 4. - С. 55-69

13. Камынин В.Д. Современные представления о степени готовности промышленности России к Первой мировой войне (на материалах Уральского региона) // Известия Уральского федерального университета. Сер. 3 - Общественные науки. 2014. № 4 (134). - C. $48-53$

14. Кречетников А. Брусиловский прорыв: украденная победа или бесполезная бойня? // BBC NEWS Русская служба, 07.10.2016 // https://www.bbc.com/ russian/features-37235327 (дата обращения: 12.04.2020).

15. Ксюнин А.И. Народ на войне. Из записок военного корреспондента. -Пг.: Изд-во Б.А. Суворина, 1916. - С. 120.

16. Кузнецова В.В. Патриотические манифестации в России в начале Первой мировой войны // Молодой ученый. 2018. № 47 (233). - С. $176-178$.

17. Куличкин С.П. Брусилов // Куличкин С. П. Первые из первых. Полководцы Земли Русской. - M., 2011 // https://www.portal-slovo.ru/history/41690.php (дата обращения: 12.04.2020).

18. Левитин-Краснов А., Шавров В. Очерки по истории русской церковной смуты. - М.: Изд-во Крутицкого патр-го подворья, 1996. - С. 23.

19. Леонтьева Т.Г. Православное духовенство в годы Первой мировой войны // Россия и современный мир. 2014. № 2 (83). - С. $104-119$.

20. Недоступов Д.А. Эволюция общественных настроений в России в 1914 - 1918 гг. // Вестник Московского государственного областного университета. Серия: История и политические науки. 2018. № 3. - С. 8-18

21. О готовности Российской империи к Первой мировой войне // Военное обозрение, 04.08.2014 // https://topwar.ru/55524-0-gotovnosti-rossiyskoy-imperiik-pervoy-mirovoy-voyne.html (дата обращения: 12.04.2020).

22. Первая мировая война 1914-1918 // РИА Новости, 28.06.2019 // https://ria.ru/20190628/1555928824.html (дата обращения: 12.04.2020).

23. «Приказываю - умереть!» // Российский героический календарь, 17.03.2016 // http://rosgeroika.ru/podvigi-v-nasledstvo/2016/march/prikazyivayu-umeret (дата обращения: 12.04.2020).

24. Риффель И.В. Государственная религиозная политика в Вооруженных Силах России в ХХ веке: автореферат дисс. ... кан. ист. наук. - СПб., 1999. - 20 с.

25. Сидорчик А. Гений прорыва. Как царский генерал Брусилов оказался в рядах Красной Армии // Аргументы и факты, 31.08.2013 // https://aif.ru/society/ history/geniy_proryva_kak_carskiy_general_brusilov_okazalsya_v_ryadah_krasnoy_armii (дата обращения: 12.04.2020).

26. Снесарев А.Е. Письма с фронта. 1914-1917. - М.: Кучково Поле, 2012. - С. 76.

27. Церковный вестник. 1914. - С. 44, 50.

28. Цыпин В., протоиер. Взаимоотношения Церкви и государства. Канонические принципы и историческая действительность // https://azbyka.ru/otechnik/ Vladislav_Tsypin/vzaimootnoshenija-tserkvi-i-gosudarstva-kanonicheskie-printsipy-i-istoricheskaja-dejstvitelnost/ (дата обращения: 12.04.2020).

29. Шавельский Г., протопр. Русская церковь перед революцией. - М.: Артос-Медиа, 2005. - С. 445-446.

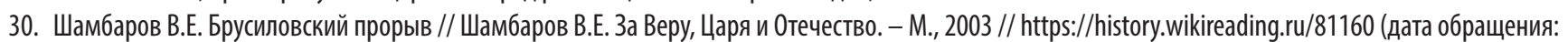
12.04.2020).

(с) Безик Юрий Иванович (bezikgeorgii@mail.ru). 